\title{
Role of the TAS2R38 Bitter Taste Receptor Gene Single Nucleotide Polymorphism in Patients With Taste Disorders
}

\author{
Byung-Jun Kang ${ }^{1}\left(\mathbb{D}\right.$, Jin-Woo Park $^{1}\left(\mathbb{D}\right.$, Sang-Yen Geum ${ }^{1} \mathbb{D}$, Un-Kyung Kim², \\ Seung-Heon Shin ${ }^{1}$, and Mi-Kyung Ye ${ }^{1}$ (D) \\ ${ }^{1}$ Department of Otorhinolaryngology-Head and Neck Surgery, School of Medicine, Daegu Catholic University, Daegu; and \\ ${ }^{2}$ Departement of Biology, College of Natural Science, Kyungpook National University, Daegu, Korea
}

\author{
미각장애 환자에서 TAS2R38 쓴맛수용체 유전자 단일염기다형성의 역할 \\ 강병준 ${ }^{1} \cdot$ 박진우 $^{1} \cdot$ 금상연 $^{1} \cdot$ 김언경 $^{2} \cdot$ 신승헌 $^{1} \cdot$ 예미경 ${ }^{1}$ \\ ${ }^{1}$ 대구가톨릭대학교 의과대학 이비인후과학교실, ${ }^{2}$ 경북대학교 자연과학대학 생명과학부 생물학전공
}

Received June 10, 2021

Revised August 23, 2021

Accepted September 1, 2021

Address for correspondence

Mi-Kyung Ye, MD, PhD

Department of Otorhinolaryngology-

Head and Neck Surgery,

School of Medicine,

Daegu Catholic University,

33 Duryugongwon-ro 17-gil,

Nam-gu, Daegu 42472, Korea

Tel $+82-53-650-4525$

Fax $+82-53-650-4533$

E-mail miky@cu.ac.kr
Background and Objectives Several studies have shown that three single nucleotide polymorphisms (SNPs) in the TAS2R38 gene demonstrate a strong association with the ability to sense the bitter taste of phenylthiocarbamide (PTC) in. We have previously reported about $T A S 2 R 38$ genotypes in normal volunteers. The aim of this study was to investigate the role $T A S 2 R 38$ gene plays in taste disorder by examining SNPs in the TAS2R 38 gene in taste disorder patients.

Subjects and Method Ninety-four patients with taste dysfunction from multiple etiologies were enrolled. The genotypes were defined by identifying SNPs on the TAS2R 38 gene. The proportion of different $T A S 2 R 38$ genotypes in the group was compared with that in the normal volunteers of our previous study. The whole mouth taste threshold tests were performed and the thresholds were compared among the three different genotypic groups.

Results The proportion of each diplotype in taste disorder patients were as follows: PAV/ PAV 36.2\% (34/94), PAV/AVI 34.0\% (32/94), and AVI/AVI 29.8\% (28/94). The proportion of AVI/AVI type was higher in the group than in the normal volunteers $(p=0.031)$. The detection and recognition thresholds of all four basic tastes were increased in the order of PAV/PAV, PAV/AVI, and AVI/AVI genotypes.

Conclusion The proportion of AVI/AVI homozygous was significantly higher in taste disorder patients than in the normal volunteers. Our findings suggest that the genotypes of TAS $2 R 38$ may represent one of the risk factors responsible for the development of taste disorders. Korean J Otorhinolaryngol-Head Neck Surg 2021;64(11):800-5

Keywords Genetics; Phenylthiocarbamide; Polymorphism, Single nucleotide; Taste disorders; Taste receptors, type2. \begin{abstract}
서 론
미각은 사람마다 느끼는 정도의 차이가 아주 크며, 이러한 각을 포함한 지각수용체 유전자의 수가 제한적임에도 불구하 고 개인별로 지각의 차이가 큰 이유로 지각수용체 유전자의 단일염기다형성(single nucleotide polymorphisms, SNPs) 차이는 결과적으로 식습관과 건강 전반에 영향을 미친다. 미 으로 인해 기능적으로 다양한 수용체들이 만들어지기 때문
\end{abstract}

This is an Open Access article distributed under the terms of the Creative Commons Attribution Non-Commercial License (https://creativecommons.org/licenses/by-nc/4.0) which permits unrestricted non-commercial use, distribution, and reproduction in any medium, provided the original work is properly cited. 
으로 알려져 있다.,2)

미각장애는 약물 복용, 구강질환, 노화, 아연 등의 무기질 부족, 수술이나 처치로 인한 신경 손상, 내분비 질환, 저작운 동장애, 타액분비 장애 등 다양한 원인에 의해 발생하며, 단 독 원인보다는 여러 가지 요인들이 복합적으로 작용하여 미 각 장애 증상을 유발하는 수가 많다. ${ }^{3-5)}$ 수술이나 외상 후 발 병한 미각장애처럼 원인이 확실한 경우가 있는 반면, 병력청 취나 이학적 검사, 혈액 검사 등을 시행하여도 뚜렷한 원인을 밝힐 수 없는 경우가 실제 임상에서는 더 많다. 미각장애 발 병에 유전적 요인이 있을 것이라는 가설하에 몇몇 연구들이 보고되어 있으며, phenylthiocarbamide (PTC) 맛에 대한 민 감성 차이에 대한 연구도 그 중 하나이다. 인간은 합성화학 물질인 PTC의 쓴맛을 느끼는 미각인(taster)과 느끼지 못하 는 미맹인(non-taster)으로 양분되며, 이것은 7번 염색체에 있는 TAS2R38 유전자의 SNPs에 의해 결정된다고 알려져 있다. ${ }^{6-8)}$

Doty와 De Fonte" 는 다양한 원인으로 인한 화학감각장 애 환자 943명을 대상으로 PTC 맛에 대한 민감도를 조사하 여 PTC 미각인의 비율이 $54 \%$, 미맹인의 비율이 $46 \%$ 라 보고 하였다. 북아메리카 인구를 대상으로 조사된 11 개 연구 결과 로부터 계산된 미각인 비율의 중간값인 $76.5 \%$ 와 비교해 볼 때, 이들 화학감각장애 환자에서 미각인의 비율이 통계적으로 유의하게 낮았다. 또 이들 미각장애 환자에서 쓴맛뿐 아니라 단맛, 신맛, 짠맛의 초역치농도를 감지 및 인지하는 능력이 PTC 미각인이 미맹인보다 더 우수했다. 이는 PTC 맛의 민 감성을 결정하는 TAS2R38 유전자형이 미각장애의 발생이 나 중증도에 영향을 끼칠 수 있음을 시사한다.

저자들은 미각장애가 없는 정상 한국인을 대상으로 PTC 에 대한 표현형과 TAS2R38 유전자의 SNPS에 따른 유전자 형의 관계에 관해 보고한 바 있다. ${ }^{8)}$ 그러나 현재까지 미각 장 애가 있는 환자에서의 TAS2R38 유전자형의 분포와 각 유전 자형 간의 미각역치의 차이에 대한 연구는 매우 드문 실정이 다. 본 연구에서는 미각장애로 내원한 환자에서 TAS2R38 유전자의 SNPS을 조사하여 정상인과의 차이를 비교해보고, $T A S 2 R 38$ 의 유전자형에 따라 미각역치의 차이가 있는지 조 사해봄으로써, 미각장애에 있어 TAS2R38 유전자 SNPs의 역할에 대해 알아보고자 하였다.

\section{대상 및 방법}

미각장애를 주소로 2010년에서 2019년까지 대구가톨릭대 학병원 후각 및 미각 클리닉을 내원한 환자 중 본 연구에 동 의하였던 94명을 대상으로 하였다. 남성이 51명, 여성이 43명

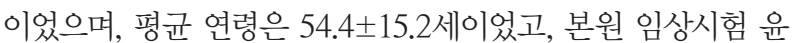
리위원회의 승인을 받아 진행되었다(CR-06-029).

미각검사 및 미각 유전자분석 연구에 대한 동의서를 받았 고, 복용 약물, 기저질환 여부, 코, 귀, 구강, 위장관, 침 분비 등 미각에 영향을 미치는 질환에 대한 설문지를 작성하게 하 였다. 전구강 화학미각검사를 시행하여, 미각장애의 유무와 정도를 측정하였다. 미각장애로 내원하였으나 실제 미각검사 에서 정상으로 측정된 사람, 후각장애의 2 차적 결과로서의 미각장애 환자, 외상성 미각장애, 수술 후 발생한 미각장애 환자는 대상에서 제외하였다.

\section{미각 검사 및 미각장애의 판정}

단맛(sucrose; 0.00977-40.0 g/mL), 짠맛 $(\mathrm{NaCl} ; 0.00488-$ $20.0 \mathrm{~g} / \mathrm{mL}$ ), 신맛(citric acid; 0.00049-2.0 g/mL), 쓴맛(quinine $\mathrm{HCl} ; 0.00002-0.1 \mathrm{~g} / \mathrm{mL}$ )의 네 가지 맛에 대한 13 단계 의 희석 용액을 만들었다. 농도에 따라 번호를 붙였으며, 가장 높은 농도인 13 번 용액부터 2 배수로 희석을 계속하여 가장 낮은 농도의 용액인 1 번 용액까지 준비하였다. ${ }^{10,11)}$

낮은 농도부터 시작하여 검사를 진행하였으며, $5 \mathrm{cc}$ 일회용 주사기에 용액을 넣어 혀의 표면에 $1 \mathrm{~mL}$ 씩 고르게 뿌린 후 입안에 머금다가 삼키게 하고 피검자에게 용액의 맛을 물어 보았다. 감지역치는 용액이 증류수와 다른 어떤 맛 느낌이 있 는 최저 농도로 하였고, 인지역치는 무슨 맛인지 맞추는 최저 농도로 하였다. 짠맛의 경우 농도를 높일 때마다 증류수로 입을 헹구게 하였으나 다른 맛은 헹구지 않고 진행하였으며, 한 가지 맛에서 다른 맛으로 넘어갈 때는 모두 증류수로 입 을 헹구게 하였다. ${ }^{10,11)}$

미각장애는 네 가지 기본 맛 중 하나 이상의 맛에서 10 번 용액 이상의 농도에서 감지 혹은 인지역치가 나타나는 경우 로 정의하였다.

\section{유전자 분석}

대상자들로부터 $10 \mathrm{~mL}$ 의 정맥혈을 채혈하여 FlexiGene DNA kit (Qiagen, Hilden, Germany)를 이용하여 genomic $\mathrm{DNA}$ 를 추출하였다. 각 $\mathrm{DNA}$ 의 양은 분광계(spectrometer) 로 측정하여 $25 \mathrm{ng} / \mu \mathrm{L}$ 로 균일하게 희석시켰으며, agarose gel 전기영동기를 이용하여 $\mathrm{DNA}$ 의 질을 알아보았다.

TAS2R38 유전자의 coding region을 특이적으로 증폭할 수 있는 primer들을 제작하여 이전 연구 ${ }^{12}$ 와 동일한 방법으 로 polymerase chain reaction (PCR) 실험을 수행하였으며 $\mathrm{PCR}$ 산물은 $1.5 \%$ agarose gel에 전기영동을 수행하여 PCR 증폭여부 및 크기를 확인하였다. ${ }^{12)}$ 증폭된 $\mathrm{PCR}$ 산물은 $\mathrm{exO}^{-}$ nuclease I (USB ${ }^{\circledR}$, Thermo Fisher Scientific, Waltham, MA, 
USA)과 alkaline phosphatase (USB ${ }^{\circledR}$, Thermo Fisher Scientific)를 넣어 섞은 후, $37^{\circ} \mathrm{C}$ 에서 1 시간 incubation 시킨 후, $80^{\circ} \mathrm{C}$ 에서 15 분간 처리하여, direct sequencing의 주형으로 이용하였다. 이후 염기서열결정은 $\mathrm{ABI} 3130 \mathrm{XL}$ 자동염기서 열분석기(Thermo Fisher Scientific)를 이용하며, DNA Sequencing Analysis software (ver 5.0; Applied Biosystems, Foster City, CA, USA)로 분석하였다.

\section{데이터 분석}

이전 연구 ${ }^{8}$ 에서 미각장애가 없는 19 세 이상의 정상 성인 남 녀 73명(남성 41명, 여성 32명, 평균연령 37.5 13.1 세)을 대상으 로 한 유전자 분석 결과와 본 연구의 대상 94 명의 TAS2R38 유전자의 SNPs를 chi-square test를 이용하여 비교 분석하 였다.

TAS2R38 유전자의 이배체형에 따라 PAV/PAV, PAV/AVI, $\mathrm{AVI} / \mathrm{AVI}$ 로 세 군으로 나눈 뒤 각각의 군의 네 가지 기본 맛 에 대한 감지 및 인지역치의 차이가 있는지 one-way ANO$\mathrm{VA}, \mathrm{Kruskal}$ Wallis test를 이용하여 분석하였으며, 사후검 정은 Dunn's procedure method를 이용하였다. 나이와 성별 을 공변량으로 사용하여 보정된 세 군 간의 네 가지 기본 맛 에 대한 감지 및 인지역치의 차이를 살펴보기 위해 다항 회 귀분석을 이용하여 분석하였으며, 사후검정은 대비를 이용 하였다.

통계적 분석법의 결과 $p$ 값이 0.05 미만일 때 통계적 유의성 이 있다고 정의하였으며 통계학적 분석은 IBM SPSS statistics 19.0 program (IBM Corp., Armonk, NY, USA)을 이용 하였다.

\section{결 과}

\section{TAS2R38 유전자형의 분포}

TAS2R38 유전자의 SNPs인 P49A, A262V, 그리고 V296I 에 대한 genotyping을 시행한 결과, $\mathrm{PAV}$ 와 $\mathrm{AVI}$ 의 두 가지 종류의 일배체형(haplotype)만 있었으며, PAV 동종접합, $\mathrm{AVI}$ 동종접합, PAV/AVI 이종접합의 3가지 형태의 유전자형 으로 분류할 수 있었다. PAV/PAV 동종접합형이 34명(36.2\%), PAV/AVI 이종접합형이 32명(34.0\%), AVI/AVI 동종접합형 이 28명(29.8\%)로 분포하는 것을 알 수 있었다(Table 1).

\section{정상인과 미각장애 환자에서 TAS2R38 유전자형의 분포의 비교}

선행연구에서 동일한 방법으로 분석하였던 정상인 73명에 서의 TAS2R38 유전자형의 분포는 PAV/PAV형이 29명(39.7\%),
Table 1. Genotype distribution of TAS2R38 in the patients with taste disorder and healthy controls

\begin{tabular}{lccc}
\hline Genotypes & $\begin{array}{c}\text { Patients with } \\
\text { taste disorder } \\
(\mathrm{n}=94)\end{array}$ & $\begin{array}{c}\text { Healthy } \\
\text { controls* } \\
(\mathrm{n}=73)\end{array}$ & p-Value $^{\dagger}$ \\
\hline PAV/PAV & $34(36.2)$ & $29(39.7)$ & 0.529 \\
PAV/AVI & $32(34.0)$ & $30(41.1)$ & 0.799 \\
AVI/AVI & $28(29.8)$ & $14(19.2)$ & 0.031
\end{tabular}

Data are presented as $\mathrm{n}(\%)$. *the data derived from reference 8; tby chi-square test

PAV/AVI형이 30명(41.1\%), AVI/AVI형이 14명(19.2\%)이었다. ${ }^{8)}$

본 연구의 미각장애 환자의 유전자형의 분포와 비교하였 을 때 미각장애 환자에서 정상인보다 PAV/PAV(환자 $36.2 \%$, 정상 $39.7 \% ; p=0.529$ ) 및 PAV/AVI (환자 $34.0 \%$, 정상 $41.1 \%$; $p=0.799)$ 형이 통계적으로 유의하지는 않았지만 적고, AVI/ $\mathrm{AVI}$ 형은 통계적으로 유의하게 많은 것을 알 수 있었다(환자 $29.8 \%$, 정상 $19.2 \% ; p=0.031$, by chi-square test) (Table 1).

\section{TAS2R38 유전자형에 따른 미각역치의 차이}

$T A S 2 R 38$ 유전자의 이배체형에 따른 세 군 간 미각역치의 차이를 분석한 결과 단맛, 짠맛, 신맛, 쓴맛의 네 가지 기본 맛 의 감지역치 및 인지역치가 PAV/PAV, PAV/AVI, AVI/AVI의 순으로 높았다.

세 군 간의 차이 및 기본 맛별 차이를 보기 위해 통계 분석 을 시행하였을 때 단맛 감지역치 및 인지역치, 짠맛 감지역치, 신맛 감지역치 및 인지역치, 쓴맛 감지역치는 $\mathrm{PAV} / \mathrm{PAV}$ 형과 $\mathrm{PAV} / \mathrm{AVI}$ 형이 동일하며 AVI/AVI형보다 통계적으로 유의하 게 낮았다. 또한 짠맛 인지역치와 쓴맛 인지역치는 PAV/AVI 형과 $\mathrm{AVI} / \mathrm{AVI}$ 형이 동일하며 $\mathrm{PAV} / \mathrm{PAV}$ 형보다 통계적으로 유 의하게 높았다(Table 2).

나이와 성별을 보정하여 TAS2R38 유전자의 이배체형에 따른 세 군 간 미각역치의 차이를 분석한 결과 단맛 감지역 치 및 인지역치, 짠맛 감지역치, 쓴맛 감지역치 및 인지역치는 $\mathrm{PAV} / \mathrm{PAV}, \mathrm{PAV} / \mathrm{AVI}, \mathrm{AVI} / \mathrm{AVI}$ 의 순으로 통계적으로 유의하 게 높았다. 짠맛 인지역치는 PAV/AVI형과 AVI/AVI형이 동 일하며 PAV/PAV형보다 통계적으로 유의하게 높았다. 신맛 감지역치 및 인지역치는 PAV/PAV형과 PAV/AVI형이 동일하 며 AVI/AVI형보다 통계적으로 유의하게 낮았다(Table 2).

\section{고 찰}

미각장애는 원인이 불명확한 경우가 많아 유전적 요인이 중요한 발병 인자 혹은 선행요인이 될 가능성이 있다. 그럼에 도 불구하고 미각장애와 연관된 유전자 연구는 드문 편이다. 
T2R38 SNPs in Taste Disorder Patients I Kang BJ, et al.

Table 2. The taste thresholds according to the genotypes

\begin{tabular}{|c|c|c|c|c|c|}
\hline Genotypes & $\mathrm{PAV} / \mathrm{PAV}^{1}$ & $\mathrm{PAV} / \mathrm{AVI} I^{2}$ & $\mathrm{AVI} / \mathrm{AVI} \mathrm{I}^{3}$ & $p$ value ${ }^{\dagger}$ & $p$ value \\
\hline Age (year) & $52.5 \pm 13.8 / 52.5(16.5)$ & $58.2 \pm 16.7 / 55.5(19.8)$ & $52.5 \pm 14.7 / 53(19.3)$ & 0.237 & \\
\hline Sex & & & & 0.864 & \\
\hline Male & $19(55.9)$ & $18(56.3)$ & $14(50.0)$ & & \\
\hline Female & $15(44.1)$ & $14(43.7)$ & $14(50.0)$ & & \\
\hline \multirow[t]{2}{*}{ Sweet-D } & $7.5 \pm 1.05 / 7.5(1)$ & $8.78 \pm 1.45 / 9(1)$ & $9.96 \pm 2.65 / 9(4.75)$ & $0.000^{*}$ & $0.000^{*}$ \\
\hline & & & & $1,2<3^{\ddagger}$ & $1<2<3^{\| \prime}$ \\
\hline \multirow[t]{2}{*}{ Sweet-R } & $8.94 \pm 1.15 / 9(2)$ & $9.69 \pm 1.73 / 9(1)$ & $10.79 \pm 2.22 / 10(4)$ & $0.002^{*}$ & $0.000^{*}$ \\
\hline & & & & $1,2<3^{\ddagger}$ & $1<2<3$ \\
\hline \multirow[t]{2}{*}{ Salty-D } & $6.94 \pm 1.35 / 7(2)$ & $7.5 \pm 1.67 / 7.5(2.75)$ & $8.43 \pm 2.43 / 8(2.75)$ & $0.035^{*}$ & $0.005^{*}$ \\
\hline & & & & $1,2<3^{\ddagger}$ & $1<2<3^{\text {II }}$ \\
\hline \multirow[t]{2}{*}{ Salty-R } & $8.91 \pm 1.96 / 8(2)$ & $8.84 \pm 1.65 / 9(2)$ & $10.39 \pm 2.36 / 10(4.25)$ & $0.017^{*}$ & $0.003^{*}$ \\
\hline & & & & $1<2,3 \ddagger$ & $1<2,311$ \\
\hline \multirow[t]{2}{*}{ Sour-D } & $6.71 \pm 1.24 / 6.5(1.25)$ & $7.59 \pm 1.79 / 7.5(3)$ & $8.39 \pm 2.25 / 8(1.75)$ & $0.002^{*}$ & $0.001^{*}$ \\
\hline & & & & $1,2<3^{\ddagger}$ & $1,2<3^{11}$ \\
\hline \multirow[t]{2}{*}{ Sour-R } & $8.82 \pm 2.32 / 8(3)$ & $10.53 \pm 2.46 / 10(3.75)$ & $10.68 \pm 2.65 / 10.5(6)$ & $0.006^{*}$ & $0.006^{*}$ \\
\hline & & & & $1,2<3^{\ddagger}$ & $1,2<3^{\| \prime}$ \\
\hline \multirow[t]{2}{*}{ Bitter-D } & $7.09 \pm 1.31 / 7(2)$ & $7.66 \pm 1.66 / 7(3)$ & $8.79 \pm 2.53 / 8.5(3.75)$ & $0.022^{*}$ & $0.001^{*}$ \\
\hline & & & & $1,2<3 \ddagger$ & $1<2<3$ \\
\hline \multirow[t]{2}{*}{ Bitter-R } & $8.29 \pm 1.51 / 8(3)$ & $8.91 \pm 2.2 / 9$ (3) & $10.14 \pm 2.66 / 10(5)$ & $0.034^{*}$ & $0.003^{*}$ \\
\hline & & & & $1<2,3^{\ddagger}$ & $1<2<3$ \\
\hline
\end{tabular}

Data are presented as concentration levels of taste solution. Values were presented by mean \pm standard deviation/median (interquartile range) or frequency (percent). *statistically significant with $p<0.05$; tby Kruskal Wallis test; :multiple comparison result by Dunn'sprocedure method; sadjusted result by multiple regression analysis with age and sex as covariate variable; "multiple comparison result by contrast. D, detection threshold; $R$, recognition threshold

저자들은 선행 연구에서 단맛의 민감도와 관련되어 있다고 알려진 TAS1R3 유전자 rs307355 및 rs35744813의 유전자형 과 대립유전자의 빈도를 조사하였으며, 미각장애 환자군과 정상군 간에 통계적으로 유의한 차이가 있었다. GNAT3 유전 자에서는 rs 7792845 의 유전자형 빈도가 미각장애 환자군과 정상 대조군 간에 유의한 차이를 나타냈었으나, 대립유전자 빈도에서는 차이가 없었다. 이는 TAS1R3 및 GNAT3 유전자 의 다형성이 미각장애와 연관이 있을 가능성을 제시해 준다 고 할 수 있다. ${ }^{12)}$ 또, Gustin이라고도 알려져 있는 carbonic anhydrase 유전자 CA6의 다형성이 TAS2R38 유전자 변이로 다 설명이 되지 않는 6-n-propylthiouracil의 쓴맛에 대한 다양성을 추가적으로 설명할 수 있다고 알려져 있으며, 짠맛 인지와도 연관이 있다는 보고도 있다. ${ }^{13)}$

본 연구는 미각 관련 유전자 중 연구가 가장 많이 이루어져 있는 TAS2R38 유전자의 SNPs로 인한 유전자형의 분포가 정상인과 미각장애 환자 사이에 차이가 있는지 살펴봄으로써 미각장애의 유전적 요인을 알아보고자 하였다. TAS2R38 유 전자의 염기쌍 $145,785,886$ 위치에 세 개의 SNP가 발견되 었다. 염기쌍 145 위치의 다형성으로 cytocine (C)이 guanine (G)이 되면 결과적으로 아미노산 49위치에서 proline이 alanine으로 부호화되며, 염기쌍 785위치에서 cytosine (C)이 thymine (T)으로 바뀌면 아미노산 262위치에서 alanine이 valine으로 바뀌게 되며, 염기쌍 886위치에서 guanine $(\mathrm{G})$ 이 adenine (A)으로 바뀌면 아미노산 296위치에서 valine이 isoleucine으로 부호화되게 된다. 이들 세 군데 TAS2R38 유 전자의 SNPs의 조합으로 생성된 일배체형들은 아미노산 변 화에 따라 이름을 붙여 부른다. 예를 들어 염기쌍 145 번 위치 에 $\mathrm{G}, 785$ 번 위치에 $\mathrm{T}, 886$ 번 위치에 $\mathrm{A}$ 의 다형성의 조합이 이 루어졌다면, 부호화되는 아미노산은 alanine, valine, isoleucine이 되고, 그 일배체형의 이름은 AVI가 되는 것이다. 가장 많은 일배체형은 PAV와 $\mathrm{AVI}$ 의 두 가지 형태이며, 그 외 AAI, $\mathrm{AAV}, \mathrm{PVI}$ 같은 세 가지 드문 형들도 보고되어 있다. ${ }^{6,14,15)}$

TAS2R38 유전자 SNPs 중 PAV/PAV형이 PTC맛에 대한 민감도가 가장 높고, AVI/AVI형이 가장 낮으며, ${ }^{1,16} \mathrm{PAV} / \mathrm{AVI}$ 형은 중간 정도의 민감도를 나타내는 것으로 보고되어 있다.,6) 그러나 저자들의 선행 연구에서 $\mathrm{AVI} / \mathrm{AVI}$ 동종접합형은 PTC 민감도가 가장 떨어졌지만, PAV/PAV 및 PAV/AVI 유전자형 은 PTC 민감도가 거의 비슷하게 나타났으며, 다른 연구에서 도 유사한 결과를 나타내었다. ${ }^{1,8,16}$ 즉 PTC 미맹검사를 시행 하면 AVI/AVI 유전자형인 사람은 PTC 미맹의 표현형으로 나타나지만, PAV/PAV형과 PAV/AVI 유전자형인 사람은 둘 다 PTC 미각인의 표현형으로 나타나서 구분이 되지 않으므 
로 이들 두 군 간의 구분은 유전자검사를 해야 가능하다.

PTC 미맹은 선천성 관절염성크레틴증(congenital arthritic cretinism), 충치, 우울증, 다운 증후군, 당뇨, 간질, 눈 질환, 갑상선종(goiters), 멀미, 비만, 파킨슨병, 조현병 등 다양한 질 환과 연관되어 있음이 여러 연구들을 통해 보고되어 있다. ${ }^{9)}$ 또한 PTC 쓴맛 민감도가 낮은 경우 상기도의 세균성 감염에 더 취약하며, 비용종이 없는 만성부비동염에서 중증도에 영 향을 끼친다고 알려져 있다. ${ }^{17)}$

이처럼 PTC 미맹과 여러 가지 질환과의 연관성에 대한 연 구는 많지만 의외로 미각장애와의 연관성에 관한 연구는 거 의 없다. Melis 등 ${ }^{18)}$ 은 미각장애에서 TAS2R38의 역할을 알 아보기 위해 33명의 미각장애 환자와 정상인 46명을 대상으 로 PTC에 대해 느끼는 맛의 강도를 유전자형에 따라 비교해 보았다. 미각장애 환자 중 $\mathrm{PAV} / \mathrm{PAV}$ 동종접합형이 PTC맛을 가장 강하게 느꼈으며, PAV/AVI 유전자형, AVI/AVI형, 기타 드문 유전자형들은 비슷한 강도로 낮게 느꼈다. 이러한 결과 로 미각장애 환자에서 PAV 일배체형만으로는 TAS2R38 수 용체의 높은 반응을 유발하는데 불충분하며, AVI 일배체형 이 미각장애 발생에 위험인자일 가능성을 제시하였다. 본 연 구에서 미각장애 환자에서 TAS2R38 유전자형은 PAV/PAV 형이 34명(36.2\%), PAV/AVI형이 32명(34.0\%), AVI/AVI형이 28명(29.8\%)로 나왔으며, 이는 미각장애가 없는 정상인을 대 상으로 한 선행 연구 ${ }^{8)}$ 에서의 결과인 PAV/PAV형 29명(39.7\%), PAV/AVI형 30명(41.1\%), AVI/AVI형 14명(19.2\%)와 비교할 때 $\mathrm{PAV} / \mathrm{PAV}$ 형 및 $\mathrm{PAV} / \mathrm{AVI}$ 형이 적고, $\mathrm{AVI} / \mathrm{AVI}$ 형이 유의하게 많았다( $p=0.031$, by chi-square test) (Table 1). 이는 TAS2R38 유전자형 중 AVI/AVI형이 미각장애 발병에 위험인자가 될 가능성이 있음을 시사한다.

PTC 미맹인의 빈도는 미국 백인이나 아랍인은 약 $30 \%-$ $40 \%$, 아시아인, 아프리카인, 미국 인디언은 약 $10 \%-20 \%$ 정도 로 인종적 및 지역적으로 차이가 있으며, 전 세계적으로 평균 약 $25 \%$ 정도를 차지한다고 보고되고 있다. ${ }^{7)}$ Chang 등 ${ }^{19)}$ 은 한 국인 정상 성인에서 미맹인의 비율이 $13 \%$, Hong 등 ${ }^{20)}$ 은 $20 \%$ 라고 하였다. 저자들의 연구에서는 미맹인의 비율이 $19.2 \%$ 였 다. ${ }^{8)}$ 이처럼 PTC 미맹인의 비율은 보고마다 차이가 크기 때 문에 다른 연구 데이터와 비교하는 것은 의미가 없고 동일 인종 및 지역에서 동일한 기준(cut-off value)으로 연구한 데 이터를 비교하는 것이 중요하다.

정상인을 대상으로 한 코호트 연구에서 미각인이 미맹인 보다 쓴맛 뿐만 아니라 다른 맛도 더 강하게 느낀다고 보고된 바 있다. ${ }^{21,22)}$ 화학감각장애 환자를 대상으로 한 연구에서도 PTC 미각인이 미맹인보다 쓴맛뿐 아니라 단맛, 신맛, 짠맛의 초역치농도를 감지 및 인지하는 능력이 더 우수했다.9) 이 연
구는 미각장애 환자를 대상으로 한 드문 연구 중 하나이지만, $\mathrm{PTC}$ 미각검사에 의한 표현형으로 대상을 구분하여서 정확 성이 떨어진다는 단점이 있다. 본 연구에서는 미각장애 환자 에서 TAS2R38 유전자형에 따라 미각역치의 차이가 있는지 를 측정하였다. 유전자형에 따라 역치의 평균의 차이가 관찰 되었으며, 단맛, 짠맛, 신맛, 쓴맛 등 네 가지 기본 맛의 감지 및 인지역치가 PAV/PAV, PAV/AVI, AVI/AVI의 순으로 높은 것을 알 수 있었다(Table 2). 이러한 결과는 TAS2R38 유전자 의 SNPs가 미각장애의 중증도에도 영향을 끼칠 수 있음을 시사한다고 할 수 있다.

저자들은 미각장애 환자에서 TAS2R38 유전자의 SNPs의 역 할에 대해 알아보고자 하였다. 미각장애 환자에서 TAS2R38 유전자형 중 $\mathrm{AVI} / \mathrm{AVI}$ 형이 정상인에서의 비율보다 더 많았 고, 단맛, 짠맛, 신맛, 쓴맛의 감지 및 인지역치가 더 높아 미 각저하의 정도도 더 심했다. 이러한 결과는 미각장애의 발병 에 TAS2R38 유전자의 SNPs가 어느 정도 관여할 가능성을 시사한다. SNP 연구는 이미 암, 천식, 동맥경화 등 주요 질병 의 원인 유전자 발굴을 위한 유전자 분석의 표지로 이용되고 있다. 본 연구를 통하여 미각장애에 대해서도 분자유전학적 진단 및 병인 연구에 적용될 가능성을 보여주며 향후 더 많 은 연구가 필요할 것으로 생각한다.

\section{Acknowledgments}

None.

\section{Author Contribution}

Conceptualization: Mi-Kyung Ye. Data curation: Byung-Jun Kang, Sang-Yen Geum, Un-Kyung Kim, Seung-Heon Shin. Formal analysis: Byung-Jun Kang, Jin-Woo Park, Seung-Heon Shin, MiKyung Ye. Supervision: Mi-Kyung Ye. Writing — original draft: Byung-Jun Kang, Mi-Kyung Ye. Writing — review \& editing: MiKyung Ye.

\section{ORCIDs}

Mi-Kyung Ye https://orcid.org/0000-0003-3732-9670

Byung-Jun Kang https://orcid.org/0000-0002-5263-8079

Jin-Woo Park https://orcid.org/0000-0003-0123-619X

Sang-Yen Geum https://orcid.org/0000-0001-6996-5618

\section{REFERENCES}

1) Bufe B, Breslin PA, Kuhn C, Reed DR, Tharp CD, Slack JP, et al. The molecular basis of individual differences in phenylthiocarbamide and propylthiouracil bitterness perception. Curr Biol 2005;15(4):322-7.

2) Prodi DA, Drayna D, Forabosco P, Palmas MA, Maestrale GB, Piras $\mathrm{D}$, et al. Bitter taste study in a sardinian genetic isolate supports the association of phenylthiocarbamide sensitivity to the TAS2R 38 bitter receptor gene. Chem Senses 2004;29(8):697-702.

3) Lim GH, Shin SH, Ye MK. Clinical investigations in patients with taste disorder. Korean J Otorhinolaryngol-Head Neck Surg 2009; 52(5):413-8.

4) Ye M. Diagnosis and treatment of taste disorder. J Clinical 
Otolaryngol 2007;18(1):28-32.

5) Deems DA, Doty RL, Settle RG, Moore-Gillon V, Shaman P, Mester AF, et al. Smell and taste disorders, a study of 750 patients from the University of Pennsylvania Smell and Taste Center. Arch Otolaryngol Head Neck Surg 1991;117(5):519-28.

6) Kim UK, Jorgenson E, Coon H, Leppert M, Risch N, Drayna D. Positional cloning of the human quantitative trait locus underlying taste sensitivity to phenylthiocarbamide. Science 2003;299(5610): 1221-5.

7) Guo SW, Reed DR. The genetics of phenylthiocarbamide perception. Ann Hum Biol 2001;28(2):111-42.

8) Ye MK, Shin TH. Relationship between PTC genotype and taste phenotype in normal volunteers. Korean J Otorhinolaryngol-Head Neck Surg 2008;51(12):1124-8.

9) Doty RL, De Fonte TP. Relationship of phenylthiocarbamide (PTC) taster status to olfactory and gustatory function in patients with chemosensory disturbances. Chem Senses 2016;41(8):685-96.

10) Lee JW, Son HJ, Shin SH, Rhyu MR, Kim JY, Ye MK. Differences in taste thresholds according to sex and age groups in Korean. Korean J Otorhinolaryngol-Head Neck Surg 2014;57(10):692-7.

11) Lee JW, Shin SH, Rhyu MR, Kim JY, Ye MK. The effect of aging on taste thresholds in Korean. Korean J Otorhinolaryngol-Head Neck Surg 2013;56(5):286-90.

12) Bae JW, Kim UK, Kwon TJ, Choi SJ, Ye MK. Polymorphisms of TASIR3 and GNAT3 genes are associated with patients with taste disorder. J Life Sci 2011;21(3):412-6.

13) Feeney EL, Hayes JE. Exploring associations between taste perception, oral anatomy and polymorphisms in the carbonic anhydrase (gustin) gene CA6. Physiol Behav 2014;128:148-54.

14) Kim UK, Drayna D. Genetics of individual differences in bitter taste perception: Lessons from the PTC gene. Clin Genet 2005; 67(4):275-80.

15) Wooding S, Kim UK, Bamshad MJ, Larsen J, Jorde LB, Drayna D. Natural selection and molecular evolution in PTC, a bitter-taste receptor gene. Am J Hum Genet 2004;74(4):637-46.

16) Duffy VB, Davidson AC, Kidd JR, Kidd KK, Speed WC, Pakstis AJ, et al. Bitter receptor gene (TAS2R38), 6-n-propylthiouracil (PROP) bitterness and alcohol intake. Alcohol Clin Exp Res 2004; 28(11):1629-37.

17) Rowan NR, Soler ZM, Othieno F, Storck KA, Smith TL, Schlosser RJ. Impact of bitter taste receptor phenotype upon clinical presentation in chronic rhinosinusitis. Int Forum Allergy Rhinol 2018;8(9):1013-20.

18) Melis M, Grzeschuchna L, Sollai G, Hummel T, Tomassini Barbarossa I. Taste disorders are partly genetically determined: Role of the TAS2R38 gene, a pilot study. Laryngoscope 2019;129(9):E30712.

19) Chang WI, Chung JW, Kim YK, Chung SC, Kho HS. The relationship between phenylthiocarbamide (PTC) and 6-n-propylthiouracil (PROP) taster status and taste thresholds for sucrose and quinine. Arch Oral Biol 2006;51(5):427-32.

20) Hong JH, Chung JW, Kim YK, Chung SC, Lee SW, Kho HS. The relationship between PTC taster status and taste thresholds in young adults. Oral Surg Oral Med Oral Pathol Oral Radiol Endod 2005;99(6):711-5.

21) Bartoshuk LM, Duffy VB, Lucchina LA, Prutkin J, Fast K. PROP (6-n-propylthiouracil) supertasters and the saltiness of $\mathrm{NaCl}$. Ann N Y Acad Sci 1998;855(1):793-6.

22) Bartoshuk LM, Duffy VB, Miller IJ. PTC/PROP tasting: Anatomy, psychophysics, and sex effects. Physiol Behav 1994;56(6):1165-71. 